\title{
РЕАЛІЗАЦІЯ ІНТЕГРАТИВНО-ДІЯЛЬНІСНОГО ПІДХОДУ В ПІДГОТОВЦІ ФАХІВЦІВ СЕСТРИНСЬКОЇ СПРАВИ
}

\author{
О. В. Ткалич
}

\author{
Кіровоградський медичний фаховий коледж ім. $є$. й. Мухіна
}

\begin{abstract}
За умов системної модернізації освітньої сфери в медичних коледжах України здійснюють низку заходів з оновлення змісту, форм і технологічного забезпечення освітнього процесу. Сучасна інноваційна медична освіта поступово набуває спрямованості на формування і розвиток у майбутніх спеціалістів сестринської справи базового ядра компетентностей, а також необхідного переліку знань, умінь і навичок, що становлять зміст конкретних загальних і професійних компетентностей.
\end{abstract}

\section{IMPLEMENTATION OF INTEGRATIVE-ACTIVITY APPROACH IN TRAINING OF NURSING STUDENTS}

\author{
O. V. Tkalych
}

\section{Ye. Mukhin Kirovohrad Medical Professional College}

Under the conditions of systematic modernization of the educational sphere, a number of measures are being implemented in the medical colleges of the Ukraine to update the content, forms and technological support of the educational process. Modern innovative medical education gradually becomes more and more focused on the formation and development of a complex core of competences for future nurses, as well as the essential knowledge and skills making up the content of specific general and professional competences.

Вступ. Сучасний сестринський процес охоплює як мінімум п'ять етапів: збір анамнезу, виявлення потреб пацієнта (встановлення цілей), планування допомоги, спрямованої на задоволення виявлених потреб (проблем), реалізацію плану, оцінку результатів. У дослідженні Т. Кир'ян ґрунтовно розглянуто всі етапи сестринського процесу, зарубіжний досвід і формування сестринської практики в різних країнах. Як пріоритети дослідниця окреслює необхідність активної участі населення в розвитку медсестринської практики:

1) вміння відповідати на зміну вимог у сфері охорони здоров'я науковою дійсністю, суспільною доступністю, високою якістю;

2) доступність для всіх і, передусім, для найбільш нужденних, тобто загальнодоступність до охорони здоров'я, зокрема в домашніх умовах, в сім'ї [5], а також за допомогою телемедицини. Тобто в основі високоефективної медичної сестринської практики лежить сестринський процес, здійснення якого не

(C) О. В. Ткалич, 2021 видається можливим, якщо фахівець не володіє спеціальними інтегрованими знаннями, які становлять функціональне ядро професійних компетентностей.

Основна частина. До сьогодні педагогіка накопичила значний фонд робіт із проблем модернізації середньої медичної освіти. Однак нові соціальні реалії покликані враховувати ту обставину, що медичні коледжі здійснюють свою діяльність, враховуючи інтереси різних сторін. 3 одного боку, вони підпорядковуються вимогам державної політики в сфері медичної освіти [3], керуючись загальними завданнями в стратегії модернізації професійної освіти. 3 іншого боку, вони $\epsilon$ виконавцями замовлення з боку системи охорони здоров'я конкретного регіону і соціуму. Водночас фундаментом підготовки спеціалістів сестринської справи стає інтегруюча тріада процесів в єдності професійної освіти, дослідницької діяльності та сестринської практики.

За умов модернізації освітніх структур у системі середньої професійної освіти велике значення надають використанню класичних та інноваційних під- 
ходів, впровадженню в освітній процес інтенсивних методів і технологій навчання. Не менш важливою вимогою є створення спеціальних педагогічних умов для інтегрованої підготовки спеціалістів сестринської справи з орієнтацією на запити практики охорони здоров'я. Зокрема, однією з таких умов $\epsilon$ підготовка медичних сестер за інтегрованими освітньо-професійними програмами, що дає змогу поєднувати навчання і професійне навчання студентів [2]. Саме в межах цього завдання в медичній освіті нині здійснюється поєднання освітніх і професійних стандартів. Відзначимо, що професійні стандарти до сьогодні розроблені майже з усіх напрямів медичної діяльності та $\epsilon$ орієнтиром для розробки компетентнісної моделі фахівця.

Навчання за умов «коледж - медична організація» дає змогу координувати методичну роботу медичного коледжу щодо вдосконалення як структури, так і змісту програм підготовки медичних сестер. Водночас підготовку кадрів здійснюють з урахуванням потреб практики. Окрім того, навчання за умов медичних організацій дає змогу безпосередньо знайомити студентів із новими технологіями і сучасними формами організації сестринського процесу, а також об'єктивізувати контроль якості підготовки та освоєння загальних і професійних компетентностей [4]. Ядро цих компетентностей дасть змогу медичній сестрі не лише ефективно виконувати свої безпосередні функції, а й систематично переробляти потужний потік професійно значущої інформації, інтегрувати знання з різних сфер у свою діяльність.

З позиції значущості інтегративно-діяльнісного підходу до підготовки компетентного фахівця відзначимо ще одну особливість компетентнісного ядра особистості, яке полягає в тому, що структура будьяких компетентностей не обмежується переліком необхідних для їхньої реалізації знань, умінь і навичок та особистісних якостей (милосердя, відповідальність, емпатія, доброзичливість, толерантність, етичність, врівноваженість, скромність).

Таким чином, передбачаючи спрямованість на забезпечення зв'язку між навчанням і професійним розвитком, інтегративно-діяльнісний підхід забезпечує також розвиток інтелекту, пізнавальних можливостей, активності, самостійності духовних сил студентів [6]. Тобто, по суті, мова йде про системну професійну соціалізацію фахівців сестринської справи. Цей процес починається на етапі навчання студента в медичному коледжі та триває протягом всього професійного життя і діяльності. Новий погляд на систему середньої медичної освіти з позиції використання інтегративно- діяльнісного підходу дає змогу розглядати феномен освіти як структуру, яку відрізняє:

- інтегрована міждисциплінарна організація змісту сестринської освіти;

- спрямованість на розвиток духовності та гуманістичних складових у структурі особистісних характеристик медичних сестер;

- інноваційний і активний характер навчально-професійної діяльності майбутніх спеціалістів сестринської справи;

- перепрофілювання освітнього процесу коледжу з трансляції знань і професійних вмінь на завдання організації керованого самонавчання студентів.

Різні підходи до організації керованого самонавчання на сьогодні впроваджує і вища медична освіта [6]. Незважаючи на відмінність цих підходів, мова неодмінно йде про високотехнологічну з дидактичної позиції, перспективну, надактивну форму організації навчальної діяльності. В цьому аспекті пріоритетним стає концентрування змісту сестринської освіти на основі інтегрованих завдань, які поетапно ускладнюють [7].

У практиці в основному розглядається інтеграція компонентів змісту освіти, що розвивається в напрямку системності та укрупнення компетентностей студентів. Свою реалізацію це знаходить у створенні, наприклад, інтегрованих курсів (сестринська допомога в хірургії, основи реаніматології, медицина катастроф) [1]: вивчивши теорію і отримавши практичні навички на заняттях з окреслених дисциплін (навчальна практика в доклінічних кабінетах, виробнича практика в закладах охорони здоров'я), студент реалізує навички компетентного фахівця сестринської справи.

У процесі формування компетентнісного ядра фахівця необхідно створити особливі умови середовища, які й будуть важелем для професійного розвитку. У формуванні середовища необхідно враховувати такі можливості, як:

1) просування професійних компетентностей студентів у реалізації медсестринської діяльності;

2) розвиток розуміння ціннісних уподобань майбутньої спеціальності;

3) стимулювання цільової спрямованості на дослідницьку роботу в майбутній професійній діяльності;

4) забезпечення розуміння соціальної значущості сестринських досліджень і доцільності формування дослідницьких умінь в освітньому процесі медичного коледжу;

5) розробка і реалізація ситуаційних завдань з інтегрованих дисциплін. 
Вирішення цього завдання вимагає розробки практико-орієнтованих інтегрованих дослідних завдань проблемного характеру. Проблемність завдання досягається створенням ситуації, в якій висунута проблема визначається як пізнавальні труднощі, сприяє спонуканню інтересу та цілі їі рішення, і вимагає засвоєння нових (інтегрованих) знань. На думку А. Амірова, проблемна ситуація визначається такими складниками, як: невідомі знання, протиріччя, когнітивний інтерес як внутрішня умова, що спрямовує розумову діяльність учнів до «відкриття» нового [1]. Це, безумовно, так, однак варто відзначити, що видимою умовою ефективного вирішення завдань стає необхідність забезпечення особистої значущості інтегрованого ситуаційного завдання. Інтегровані професійно спрямовані завдання доцільно розробляти на основі ситуацій з реальної практики або як штучно змодельовані. Наведемо лише один приклад такого завдання.

Завдання. Медична сестра стала очевидцем аварії на трасі (перекинувся автобус). Найближчий населений пункт знаходиться в 40 кілометрах. Постраждалих багато, з різними видами травм. Одна з постраждалих отримала комбіновану травму (ушкоджена стегнова артерія, травма грудної клітки та шиї). об'єктивно: деформація правого стегна, садна і забиті місця обличчя і волосяної частини голови. Пульс 110 ударів на хвилину, артеріальний тиск 80/60 мм рт. ст. Під час обережної пальпації правого стегна постраждала різко скрикнула від болю. Завдання:

1. Визначте і обґрунтуйте невідкладний стан.

2. Складіть алгоритм дій медичної сестри (хірургічного профілю, реанімаційної допомоги і дії при медицині катастроф).

\section{СПИСОК ЛІТЕРАТУРИ}

1. Амиров А. Ф. Использование технологий управляемого решения задач успешной профессиональной социализации будущих врачей / А. Ф. Амиров // Вестник ОГУ. - 2017. - № 10 (210). - С. 9-13.

2. Варава О. Б. Модель розвитку інформаційно-аналітичної компетентності майбутніх медичних сестер / О. Б. Варава // Медсестринство. - 2018. - № 3. - С. 38-41.

3. Галузевий стандарт вищої освіти України спец. : 6.110102. «Сестринська справа» МОН України. - К., 2012. -28 c.

4. Гордійчук С. В. Європейський та український досвід підготовки кадрів для медсестринства / С. В. Гордійчук, Н.П. Леонченко // Наукові записки Тернопільського національного педагогічного університету імені Володимира Гнатюка. - 2011. - № 4. - С. 195-200. - (Серія «Педагогіка»).
3. Продемонструйте на фантомі тимчасову зупинку артеріальної кровотечі, накладення шин Крамера і коміра Шансу.

Вирішення подібних завдань сприяє комплексному засвоєнню і закріпленню майбутніми фахівцями сестринської справи змісту дисциплін (теоретичних знань) та їх діяльнісної складової. Водночас не лише в плані інтеграції навчальних дисциплін (сестринська справа в хірургії, основи реаніматології, медицина катастроф), а й охоплює інші медичні та гуманітарні дисципліни. Такий підхід сприяє формуванню інтегрованого мислення. У окремому вирішенні надання першої та медичної допомоги потрібно було б втручання різних фахівців: хірургічна медична сестра зупинила 6 кровотечу і наклала шину; реанімаційна сестра стежила $б$ за життєвими показниками і не допускала розвитку термінального стану; служба медицини катастроф виконувала 6 евако-транспортну функцію. Перевага мобільного фахівця сестринської справи 3 інтегрованим мисленням - це вирішення цієї ситуації зусиллями одного фахівця.

Висновки. Правильно розроблене і повноцінно функціонуюче освітнє середовище дає змогу вирішувати ті питання, які неможливо вирішити в межах аудиторних занять. Вищий рівень професіоналізму медичної сестри характеризується її компетентністюу своїй професії, а успішне формування компетентності уможливлюється на основі реалізації інтегративнодіяльнісного підходу до підготовки фахівця сестринської справи.

5. Кир'ян Т. І. Реалізація особистісно-орієнтованого підходу до навчання і формування особистості майбутніх медсестер у ВНЗ України I-ІІ рівнів акредитації (кінець XX - початок XXI ст.) / Т. І. Кир'ян // ScienceRise. Pedagogical Education. - 2017. - № 1. - С. 24-27.

6. Ястремська С. О. Теорія і методика професійної підготовки майбутніх магістрів сестринської справи у вищих медичних навчальних закладах засобами дистанційного навчання : дис. ... доктора пед. наук : 13.00.04 / С. О. Ястремська. - Хмельницький, 2018. - 358 с.

7. Benton D. International issues and trends in nursing regulation / D. Benton // Journal of Nursing Regulation. 2011. - Vol. 4 (1). - P. 4-8. 